\title{
MARÍA ZAMBRANO Y SU VISIÓN DE AMÉRICA LATINA LECTURA DE CUATRO ENSAYOS
}

Al contemplar el vasto panorama que constituye la historia del exilio español, llama la atención, entre muchas otras cosas, el hecho de que, si bien la gran mayoría de los exiliados permanecieron fijos en un mismo lugar durante más de veinte o treinta años, para otros la expulsión de su patria supuso una larga experiencia de errancia, de breves escalas sucesivas en países muy diversos. María Zambrano parece un ejemplo preclaro de esta segunda categoría de exiliados, a quienes podríamos llamar "los trashumantes". Porque si bien en los primeros meses de 1939, como muchos otros compatriotas suyos, la filósofa malagueña logró escaparse a Francia, y luego, desde Francia trasladarse a México, su estancia en México resultó ser muy breve. Ya para enero de 1940 se encontraba viviendo en La Habana. Y aunque permaneció en Cuba hasta 1946, durante esos seis años hizo visitas muy frecuentes a la isla de Puerto Rico, país que de este modo llegó asimismo a conocer muy bien. Pero la historia de sus viajes no se detiene allí. En 1946 Zambrano volvió a Europa, concretamente a París, donde se reunió con su hermana, pero dos años más tarde se encontraba otra vez en Cuba, desde donde hizo un breve viaje a la capital mexicana en 1949. En el mismo 1949 visitó Italia (Florencia, Venecia, Roma) y, al año siguiente, Francia, donde permaneció hasta 1951, fecha en que volvió una vez más a La Habana. Se despidió de América por última vez en junio de 1953, cuando, junto con su hermana Araceli, salió en barco rumbo a Italia. Los otros treinta años de su exilio los pasó en Europa, repartiendo su tiempo entre Italia, Suiza y Francia, antes 
de volver por fin a su patria, para nunca más salir de ella, el 20 de noviembre de $1984^{1}$.

Este es sólo un rápido sumario de todas las idas y venidas que María Zambrano hiciera durante su largo exilio. Aun resumida así, de manera tan esquemática y breve, la historia resulta algo insólita, sobre todo cuando uno recuerda la absoluta insolvencia económica en que la escritora pasó la mayor parte de su exilio. (Por lo visto, en uno y otro lados del Atlántico, ella contó con la generosa ayuda de mecenas que, conscientes de la importancia de su trabajo, no sólo tomaron medidas para que no se muriera de hambre, sino que también le ayudaron a financiar algunas de estas largas travesías.) Pero más que insistir sobre los aspectos materiales de la vida personal de María Zambrano, en lo que sigue quisiera reflexionar un poco sobre las posibles repercusiones de esta vida errante en el pensamiento de la escritora. ¿Qué fue lo que descubrió en América? Puede ser que su decisión de trasladarse a México en la primavera de 1939 haya correspondido a imperativos inmediatos de orden práctico; es decir, a la urgente necesidad de salvarse del naufragio que todos los republicanos entonces padecían. Pero si en 1948, de regreso en París, ella decidió volver una vez más a América Latina, y si en 1951 todavía hizo otro viaje más de Europa a América, seguramente fue porque algo muy fuerte le atraía en ese otro lado del mundo. ¿Cuál fue el atractivo que había descubierto en esas otras tierras de lengua española? ¿Y cómo reconciliaba este atractivo con la fuerte gravitación hacia Europa que evidentemente vivía al mismo tiempo?

Las páginas que siguen pretenden ofrecer un breve comentario sobre la visión que María Zambrano se formó de los tres países latinoamericanos en que vivió durante los primeros años de su exilio: México, Puerto Rico y Cuba. Aunque encabezan el trabajo unas consideraciones también sobre la interpretación que ella quiso dar a los meses que pasó en Santiago de Chile al principio de la Guerra Civil. Se me objetará, tal vez, que su viaje a Chile queda fuera de la época que se suele relacionar con el exilio español. Y no les faltará razón a quienes así opinen. En mi defensa diré, primero, que ningún estudio de la expe-

1 Sigo aquí y en adelante la "Síntesis biográfica" que publicó Jesús Moreno SAnz en María Zambrano. 1904-1991. De la razón cívica a la razón poética, eds. J. Moreno Sanz y F. Muñoz, Publicaciones de la Residencia de Estudiantes-Fundación de María Zambrano, Madrid, 2004, pp. 37-80. 
riencia americana de María Zambrano, por somera que fuese, sería completo si no se tomara en cuenta ese primer viaje suyo al Nuevo Mundo. Por otra parte, me pregunto en qué sentido difiere lo que en 1937-1938 Zambrano escribió sobre su estancia en Chile con respecto a lo que, por ejemplo, escribió José Moreno Villa, por las mismas fechas, sobre sus primeras impresiones de México, en textos que suelen considerarse como parte de su obra del exilio. Moreno Villa pensó volver a su país en cuanto las circunstancias se lo permitieran, al igual que María Zambrano. Pero ¿el hecho de que a los seis meses el poeta-pintor no logró volver a España y la filósofa sí, nos obliga a dar una clasificación diferente a todo cuanto escribieron los dos entonces? En realidad, en la trayectoria de los republicanos resulta a menudo muy difusa la línea que separa la época de la Guerra Civil de lo que corresponde a la experiencia del exilio.

Para ilustrar la visión que Zambrano llegó a formular de los cuatro países, propongo comentar otros tantos ensayos suyos (uno por país). Con el fin de respetar la evolución en el pensamiento de la filósofa, dichos textos se discutirán según el orden cronológico en que fueron escritos, que no coincide exactamente con el orden en que Zambrano visitó por primera vez los cuatro países latinoamericanos que llegó a conocer. Los ensayos son "Recuerdos de un viaje. La tierra de Arauco", de 1938, "La isla de Puerto Rico. (Nostalgia y esperanza de un mundo mejor)", de 1940; "La Cuba secreta", de 1948; y "Un descenso a los infiernos", un texto inédito en vida de la autora, pero probablemente redactado hacia 1959.

\section{La tierra de Arauco}

Lo que motivó el primer viaje de María Zambrano al continente americano fue, como se sabe, el nombramiento de Secretario de la Embajada Española en Santiago de Chile que recibió su marido, Alfonso Rodríguez Aldave, en septiembre u octubre de 1936. Los dos salieron de Europa en el "Santa Rita", un barco que tras hacer escala en La Habana, recorrió el Canal de Panamá, para luego entrar en el Pacífico por el puerto de Balboa. Llegaron finalmente a Chile el 18 de noviembre. Presentada en la prensa local como "prominente escritora española que también es graduada como catedrática en filosofía”, Zambrano no tuvo tarea oficial que cumplir en la embajada, pero por eso 
mismo dispuso de más tiempo para emprender sus propios proyectos, la gran mayoría de ellos destinados a promover la causa de la República española ante un público latinoamericano². Así, apenas instalados en Santiago, ella y su marido ayudaron a lanzar una colección de libros en la Editorial Panorama de la capital chilena, que incluyeron una obra suya, Los intelectuales en el drama de España, así como Madre España, una antología de versos en homenaje a la República española firmados por Vicente Huidobro, Pablo Neruda y otros poetas chilenos del momento $^{3}$. Esta iniciativa editorial confirma la fervorosa entrega de la filósofa malagueña a la causa republicana. Pero para formarnos alguna idea de la impresión que dejó en ella el país visitado, debemos acudir más bien a "Recuerdos de un viaje. La tierra de Arauco", un breve ensayo que Zambrano posiblemente escribió tras su regreso a España en junio de 1937 y que publicó en junio de 1938, en Barcelona, en la Revista de las Españas ${ }^{4}$.

Zambrano dedica una breve sección de su ensayo a evocar el momento en que, después de atravesar el Canal del Panamá, se asoma por primera vez a la inmensidad del Pacífico. Sin embargo, la sección central de sus recuerdos, como es lógico, la guarda para su llegada a Chile. Curiosamente, su primera impresión del país resulta muy poco halagüeña: "La llegada a la tierra chilena tiene algo de llegada al fin del universo; un Finisterre por la desolación absoluta de su paisaje; tierra que es solamente tierra, desnudez de planeta, silencio mineral, campos de luna”. El

2 Véase Pamela Soto García, "Un inolvidable y decisivo viaje”, en María Zambrano 1904-1991..., pp. 103-109.

3 Otros dos libros de la colección fueron también iniciativas de María Zambrano: una Antología, con prólogo suyo, de la poesía de Federico García Lorca, y un Romancero de la guerra española, nuevamente con presentación suya. Por parte de los chilenos se publicaron (además de Madre España): Horizonte despierto, del poeta Gerardo Seguel, y Cuatro meses de guerra civil en Madrid, de Luis Enrique Délano (un amigo y colaborador estrecho de Pablo Neruda). También se anunció una antología de la obra de Rafael Alberti, seleccionada y prologada por Huidobro; pero el libro, por desgracia, no parece haberse publicado.

${ }^{4}$ Véase María Zambrano, "Recuerdos de un viaje. La tierra de Arauco”, Revista de las Españas (Barcelona), junio de 1938, núm. 102, 21-22. El texto fue reproducido poco después en El Nacional (México D.F.), 11 de septiembre de 1938, pp. 3, 5 (primera sección). El texto de la publicación española lleva una dedicatoria a Pablo Neruda que no figura en la mexicana. A continuación citaré por la edición de Revista de las Españas; en vista de la relativa brevedad del texto, no considero necesario identificar la página de donde procede cada cita. 
lector tiene la impresión de que en ese primer momento de su llegada, a María Zambrano el panorama le hubiera resultado, de hecho, del todo inhóspito, si no fuera porque de repente ella se encontrara con algún habitante del lugar y, por medio de él, con algo que la conmovía en lo más hondo de su ser: la presencia de la lengua castellana:

El hecho sencillo de oír mi propio idioma, de ver sus palabras transparentes, como si una luz interna las iluminara -"botica", "talabartería"-, me conmovía como un prodigio inesperado. Pero en seguida me di cuenta de que mi emoción mayor no era por el hecho de escuchar "mi" idioma, sino por sentirlo "nuestro", por sentirlo compartido, por sentir que algo como mi propia sangre era al mismo tiempo propio también de aquellos hombres y mujeres; que lo que llevaba como don de mi pueblo era igualmente de aquel pueblo.

Aquí, en este encuentro de un hispanohablante con otro, se ejemplifica la especie de espejismo que articula la visión no sólo cultural sino también política que María Zambrano expresa de este país latinoamericano. Y es que así como confunde el español que ella habla con el español del chileno, también confunde las aspiraciones del pueblo español con las del pueblo que acaba de conocer. Llevando esta visión especular hasta su extremo lógico, incluso llega a proyectar sobre el árido paisaje de Arauco, el perfil de otro paisaje muy distinto. Así, desde Santiago de Chile cree vislumbrar: "Algo de unas sierras azules que se llaman Guadarrama, de unas violetas que se llaman Sierra Morena, cuya pequeñez llegaba a ocultar la majestad de los Andes". En estas palabras vemos que, al proyectar España sobre Chile, Zambrano finalmente deja de percibir todo aquello que singulariza la vida del país que visita. Ve sólo una proyección de sus propias inquietudes: la Sierra Morena, a pesar de su pequeñez, finalmente oculta la majestad de los Andes. Así, sin que Zambrano parezca darse cuenta, ella empieza a retomar, a su modo, el discurso hispanizante que durante siglos había caracterizado la actitud de la metrópoli hacia sus antiguas colonias, una actitud que en otro momento de su ensayo dice, por cierto, haber superado.

Este proceso tiene otra ejemplificación muy nítida en las reflexiones que la ensayista hace sobre el roto, el hombre desempleado (y derrotado) de la capital chilena. Zambrano se angustia al contemplarlo, ya que cree descubrir en él a un hombre 
"ensimismado en un sopor casi vegetal"; es decir, a un hombre que, por carecer de cualquier estímulo cultural, no sabe pensar por sí mismo. Más importante aún, en la soledad de este hombre, que ella considera ya no humana sino cósmica, Zambrano encuentra una diferencia fundamental que finalmente separa al obrero chileno de su equivalente en España; porque para Zambrano la soledad del obrero español sí está arraigada en una tradición cultural y por lo mismo "manifiesta una voluntad", mientras que el roto, en cambio, parece no contar con ningún recurso espiritual en qué apoyarse. Pero justo en el momento mismo en que Zambrano parece reconocer la particularidad del país que visita, incurre de nuevo en una visión españolizante. Porque lo verdaderamente terrible del roto chileno, según nuestra ensayista, no es que carezca por completo de una tradición cultural, sino más bien que haya perdido conciencia de aquella tradición que alguna vez sí lo sostuviera: la española. Es decir, si bien reconoce que existe una diferencia entre los dos pueblos, el chileno y el español, es sólo para lamentarla. Refiriéndose al roto chileno, afirma:

Lo que ante todo le precisa es despertar. ¿Quién le mantiene dormido? Socialmente pesan sobre él capas sociales que viven una vida actual, al día; mas cuando él habla es con voz de Cervantes; son palabras antiguas, fórmulas de hace siglos las que su voz sedosa repite. Y entonces se concreta más la pregunta: ¿Quién lo ha dejado abandonado? ¿Quién ha dejado su mente detenida con reminiscencias de pasados siglos? ¿Quién no le siguió alimentando espiritualmente? ¿Quién le dejó en un mundo de técnica y de fuerza, sin valimiento?

Estas preguntas retóricas parecen estar dirigidas hacia dos blancos. Porque si bien los responsables directos de la incultura de la clase trabajadora de Chile serán los sucesivos gobiernos de la República chilena que la han dejado inerme ante los embates del progreso tecnológico del mundo moderno, Zambrano también insinúa que durante el mismo lapso España no ha cumplido con sus responsabilidades ante su antigua colonia (al contrario, sólo le ha dado la espalda). Sea como sea, el pasaje citado deja muy en evidencia la actitud paternalista en que Zambrano finalmente ha caído. Quiere que el pueblo chileno preste su apoyo al pueblo español, pero según ella es mucho más lo que el pueblo español puede, y debe, hacer para sus 
coetáneos en América. Es decir, finalmente, no existe "esa fraternidad imprevista" de la que ella hablaba en otro momento, sino más bien una relación filial entre Chile y la Madre España.

Como ya se ha dicho, Madre España fue el título que se puso a una antología de poesía chilena publicada con el fin de promover la causa de la República española. Según Zambrano, fue en Chile, en actos populares de adhesión a España, donde escuchó por primera vez esta frase: la Madre España. Seguramente, este hecho la animó (e incluso la autorizó) a formular su visión maternal de la antigua colonia que visitaba. En todo caso, la lectura de este ensayo demuestra cómo su encuentro con el mundo latinoamericano sólo sirvió para aumentar la trascendencia que ella concedía a la cultura española y, por ende, a la lucha de la República por defenderla. Y es que, según leemos en este texto, de la victoria de la República en la guerra española dependía la salvación, no sólo de América Latina, sino del mundo entero:

Hay millones de seres que dicen hoy "Madre España", acompañándonos con todo el corazón en nuestra lucha. Y es así que la cultura española es necesaria al mundo. Ni la técnica moderna, ni la filosofía germana, ni el pragmatismo anglosajón han podido sustituirla. La cultura humana, universal, que el hombre precisa para salir del atolladero en que se encuentra metido, sólo de nuestra lucha puede surgir.

Sería interesante comparar estas ideas con las declaraciones de otros intelectuales republicanos identificados con la causa republicana. Basta decir por ahora que, una vez perdida la guerra española, María Zambrano se fue alejando, poco a poco, de un nacionalismo tan exacerbado.

\section{LA isla de Puerto Rico}

El segundo texto que he escogido para comentar, "La isla de Puerto Rico. (Nostalgia y esperanza de un mundo mejor)", fue escrito en el verano de 1940: un momento de mucha angustia para María Zambrano, como para el mundo en general. Porque si ya para entonces se había consumado la derrota militar de la República española, el estallido poco después de la Segunda Guerra Mundial había confirmado el gran poderío del fascismo alemán, cuya expansión, tras la caída de Francia y la evacuación 
del ejército británico en Dunkerque, parecía entonces imparable. Conviene señalar estos hechos históricos porque sirven como dramático trasfondo de este segundo ensayo de Zambrano, escrito tras un viaje que la autora hizo a Puerto Rico desde La Habana, donde entonces vivía exiliada ${ }^{5}$.

Fiel expresión de la gratitud que sintiera Zambrano por los "días venturosos" que acababa de pasar en Puerto Rico, el ensayo arranca con un breve bosquejo de lo que podríamos llamar un "tratado de las islas": teoría que seguramente debía no poco a la "teología insular" que el joven poeta cubano José Lezama Lima ya llevaba algún tiempo elaborando, como bandera bajo la cual rescatar y promover las distintas expresiones que conformaban la vida cultural de su país ${ }^{6}$. Aunque, dicho esto, hay que

5 Véase M. Zambrano, La isla de Puerto Rico. (Nostalgia y esperanza de un mundo mejor), La Verónica, La Habana, 1940. Al citar de esta edición, me limito a identificar, en el cuerpo del texto (y entre paréntesis), el número de la página de cada fragmento citado. La visita de Zambrano fue motivada por una invitación a dar una serie de conferencias en la isla. La revista Nuestra España ofrece la siguiente información al respecto: "Invitada por la «Asociación de Mujeres Graduadas de la Universidad de Puerto Rico», desarrolló cursillos en la capital, San Juan, nuestra compatriota María Zambrano. Fueron éstos integrados por las siguientes conferencias: Cuatro sobre Séneca, y tres sobre Breve historia del amor en Occidente, pronunciadas en la citada Asociación. Una en el Departamento de Estudios Hispánicos de la Universidad sobre El pensamiento de Ortega y Gasset. En el Ateneo, otra conferencia sobre Unamuno en la tragedia de España. En el «Círculo de Conferencias», otra sobre Antonio Machado y tres más sobre Historia poética de la España actual: Lorca, Alberti, Emilio Prados, Cernuda y Altolaguirre. Por último, en la «Asociación de Trabajadores Sociales», pronunció otras tres conferencias sobre Orígenes de la ética". En párrafo aparte se agrega: "En Puerto Rico recibió la escritora Zambrano ofrecimientos varios, siendo muy agasajada en aquellos medios intelectuales" (anónimo, "Noticias literarias. Los intelectuales españoles en América. Conferencias de María Zambrano”, Nuestra España [La Habana], mayo de 1940, núm. 8, p. 100). Además de colaborar en la revista Asomante, durante los años cuarenta Zambrano hizo varias visitas más a Puerto Rico, que le permitieron consolidar su amistad con los intelectuales de la isla. Véanse también los 45 artículos que publicó en la revista Semana, de San Juan, entre 1963 y 1965, y que recoge Mercedes Gómez Blesa en Con Dados de Niebla. Revista de Literatura (Huelva), 2002, núms. 21/22, 5-110.

6 Véase, sobre todo, José Lezama Lima, "Coloquio con Juan Ramón Jiménez”, Revista Cubana (La Habana), enero-febrero de 1938, núm. 25; recogido en Lezama Lima, Analecta del reloj, Orígenes, La Habana, 1953, pp. 40-61. Por algo, el ejemplar del ensayo de Zambrano que el poeta y novelista cubano conservaba en su biblioteca lleva la dedicatoria: "A José Lezama Lima, quien ha sentido y pensado sobre estas islas". Recojo este dato del ensayo de Jorge Luis Arcos, "María Zambrano y la Cuba secreta", 
reconocer que la propuesta de la filósofa española contempla un panorama más amplio, al destacar la función que las islas en general han cumplido, y que pueden seguir cumpliendo, en la historia de la humanidad.

Y es que, según Zambrano, "en los momentos de crisis históricas las islas juegan un papel: el de ser imán que atrae la imaginación hacia algo primario, no corrompido todavía, de la naturaleza humana" (pp. 13-14) Teoría ésta que, a su juicio, podía (y debía) aplicarse en la crisis histórica que el mundo vivía en aquel momento. Así, en el caso particular de la autora, Puerto Rico, en cuanto isla, le devolvía una imagen completa de una civilización milenaria (la de Occidente), cuyos valores parecían a punto de desaparecer bajo la amenaza del fascismo: le devolvía no sólo un estilo de vida (un irse forjando su propia existencia), sino también aquellos principios básicos, como la democracia y la libertad, que habían permitido y fomentado esa forma creativa de vivir. La isla le había devuelto, en fin, "la imagen real de su propia vida"; le había restituido "el milagro de la integridad" (pp. 22, 24).

Hasta aquí el pensamiento de Zambrano podría interpretarse como indicativo de cierta actitud evasiva frente a los graves problemas mundiales del momento; pero nada más lejos de la verdad. Como señala el título de su ensayo, Puerto Rico constituye para la filósofa no sólo una fuente de nostalgia personal, sino también, y sobre todo, un motivo de esperanza para todos. De hecho, al ensalzar los valores culturales de la isla, lo que se propone no es evadirse de los problemas actuales, sino, al contrario, reivindicar esos valores como armas con qué combatir las fuerzas de destrucción que acechan al mundo. Es decir, sus reflexiones corresponden a una postura comprometida, que representa en cierta medida una continuación de la heroica defensa de la cultura a la que ella y muchos otros artistas e intelectuales republicanos se habían entregado durante la Guerra Civil. Aunque, dicho esto, hay que reconocer que los tiempos, desde luego, ya no son los mismos y que las miradas, por lo tanto, ahora son otras. La propuesta, efectivamente, ha cambiado. Ahora Europa está en peligro, y con ella, toda la civilización occidental. Así, en esta "terrible hora presente" (p. 25),

Orígenes: la pobreza irradiante, Editorial Letras Cubanas, La Habana, 1994, p. 89. Arcos, por cierto, es uno de los poquísimos críticos en señalar el interés de esta obra olvidada de Zambrano. 
Zambrano ya no se limita a reivindicar tan sólo la cultura de lengua española. Si América ha de salvar al Viejo Mundo (que en esto consiste finalmente la propuesta de la filósofa), las dos culturas más fuertes del continente americano, la hispánica y la sajona, tienen que reconciliar sus diferencias para ofrecer un frente unido ante la barbarie. De ahí la "empresa de radio universal” (p. 37), que, por sus históricas vinculaciones con ambas culturas, la isla de Puerto Rico, según Zambrano, estaba destinada a llevar a cabo:

todo parece conspirar para que esta pequeña isla, esta leve islita de Puerto Rico... sea el lugar donde todo ello se cuaje. La reconciliación entre el hombre hispánico, rico en su fracaso, y el hombre poderoso del Norte; la comprensión clara de la obra a realizar, conciencia y entusiasmo para la aceptación del difícil destino. El lugar, la sede de un acontecimiento universal por su trascendencia, ineludible por su necesidad (p. 45).

Desde nuestra perspectiva actual, podemos ver que Zambrano pecaba de optimista, no sólo con respecto a la posibilidad de que las dos "raíces" culturales pudieran fundirse en una nueva relación armoniosa y fecunda para todos, sino también en creer que la cultura en general, fuese cual fuese su signo, pudiera salvar al mundo de la situación inmediata en que se encontraba sumido. Y, en efecto, al hacer su propuesta, Zambrano seguramente se dejó llevar demasiado por la política panamericanista que entonces defendía el gobierno de Estados Unidos, apoyándose, al hacerlo, en su relación especial con Puerto Rico. Porque se trataba, como ahora sabemos, de una política que, lejos de acercar a las dos culturas en una nueva relación de igualdad, quiso aprovechar la coyuntura de la guerra mundial, para extender su hegemonía política y económica sobre ese hombre hispánico que Zambrano, y no por nada, define como "rico en fracaso". La historia no tardó en desmentir las aseveraciones y profecías de la filósofa y tal vez fuera por eso que, en años posteriores, nunca mostrara interés en incorporar su ensayo a ninguno de sus libros ${ }^{7}$.

${ }^{7}$ Cabe comparar este ensayo de Zambrano con las ideas expresadas por otros visitantes a la isla de Puerto Rico. Por Pedro Salinas, por ejemplo. En su famosa "Defensa del lenguaje", escrita en Puerto Rico en 1944, Salinas reconoce que la presencia en la isla de la lengua inglesa podría facilitar a los portorriqueños el conocimiento de otra gran tradición literaria y así 
Pero, errado o no en su propuesta, el ensayo merece mejor suerte, si no por otra cosa, por la luz que echa sobre la evolución que marca en el pensamiento de Zambrano con respecto a América. Superado el paternalismo, o maternalismo, que todavía en 1938, en la crónica de su viaje a Chile, quedara patente, Zambrano habla ya en términos de una relación de igualdad, consciente, en todo caso, de que la raíz que le interesa rescatar se encuentra tan enterrada en España como en América Latina: "Ya no se trata de padres e hijos, sino de seres que tienen una misma raíz, un mismo ser enterrado en el olvido. Y este ser oculto, escondido, es quien nos ha de dar fuerza y lucidez para salir de la crisis gravísima del presente. Porque es la herencia, la herencia inajenable, la herencia que no podemos dejar caer" (p. 41).

\section{La Cuba secreta}

Fueron numerosos los ensayos escritos por Zambrano en que Cuba figura como trasfondo, lo cual resulta natural si recordamos que éste fue también el país latinoamericano donde más tiempo pasó María Zambrano y donde también fue más feliz. Aunque dicho esto conviene subrayar que sus vínculos con la vida intelectual de la isla fueron tan estrechos que la autora siguió escribiendo acerca de Cuba muchos años después, durante su largo exilio en Europa. Para analizar algunas de las ideas que ella tenía sobre la isla, propongo comentar el famoso tex-

contribuir a su enriquecimiento espiritual; sin embargo, insiste que la introducción del inglés en la isla no corresponde a propósitos culturales de esta índole, sino a una simple "utilidad negociante"; por lo mismo, finalmente termina por denunciar la agresividad con que el inglés tiende a subvertir "la constitución natural" de la lengua española (véase "Defensa del lenguaje", $E l$ defensor, Alianza, Madrid, 1983 [1948], pp. 275-327). JuAn RAmón JimÉnEz, en cambio, que también pasó largas temporadas en la isla, llegando incluso a morirse allí, no parece haberse preocupado mayormente por la variedad cultural que veía a su alrededor, tal vez confiado en que el portorriqueño sabría resistir el embate de los sectas protestantes, como también de "esas camisitas y esos calzoncillos norteamericanos con flores y pájaros de todos los colores" que traían consigo. Como poeta se fijó más bien en la hermosura física de la isla, que le fascinaba, sobre todo por ser "una tierra femenina" (véanse los textos reunidos bajo el título general de "Isla de la simpatía", en Y para recordar por qué he venido, ed. F.J. Blasco, Pre-Textos, Valencia, 1990, pp. 267-277). 
to que publicó en 1948, en la revista Orígenes, bajo el título de "La Cuba secreta"8.

Cuba es uno de los países latinoamericanos que suelen despertar más recuerdos de su patria en los españoles que lo visitan, sobre todo si son andaluces. Por lo mismo, no debe sorprender a nadie descubrir que Zambrano empiece su ensayo sobre "La Cuba secreta" subrayando las coincidencias - de aire, de luz, de sombra- que ella encuentra entre La Habana y el pueblo mediterráneo en que ella nació. Estas similitudes explican en cierta medida el gran apego que desde un primer momento ella siente por esta isla. Y, sin embargo, lo curioso es que ella da un giro nuevo a esta experiencia de déjà vu, al insistir que lo que despierta la honda sensación de familiaridad no son las formas en sí del mundo tropical que tiene delante de sí, sino más bien la potencialidad de vida nueva de donde todas estas formas parecen brotar. Por ello afirma, con mucha gracia, que lo que ha experimentado en Cuba es el regreso, no a la Andalucía de su niñez y juventud, sino a una especie de "patria prenatal", donde todo se vive como "desnudo palpitar en la oscuridad" o como "puro sueño del ser a solas con su cifra". Es decir, más que la conformación de tal o cual realidad, con proyecciones muy específicas en el tiempo y en el espacio, Cuba encarna para ella un gran potencial de energía creadora, esa posibilidad de nacer una y otra vez a la vida que, según ella, sólo puede depararnos la poesía. "Y así -nos explica Zambrano- sentí a Cuba poéticamente, no como cualidad sino como substancia misma. Cuba: substancia poética visible ya. Cuba: mi secreto" (p. 107).

Lo que le confirma esta identificación de Cuba con la sustancia poética misma es el hecho, tal vez azaroso, de que la estancia de Zambrano en la isla coincide con el nacimiento a la poesía de toda una generación de escritores que, durante los años cuarenta, y aglutinados alrededor de la figura excepcional de José Lezama Lima, se ha ido dando a conocer en revistas como Espuela de plata, Nadie Parecía, Clavileño, Poeta y Orígenes. Y de ahí

8 M. Zambrano, "La Cuba secreta", Orígenes (La Habana), 1948, núm. 20, 3-9. Se trata de una extensa reseña de la antología Diez poetas cubanos. 1937-1947 (Orígenes, La Habana, 1948), preparada por Cintio Vitier. El ensayo fue recogido por Jorge Luis Arcos en su edición de MARía Zambrano, $L a$ Cuba secreta y otros ensayos (Endymion, Madrid, 1996, pp. 106-115). Cito por el libro de Arcos, que recoge una amplia selección de lo publicado por Zambrano en y sobre Cuba. Al hacerlo, me limito a identificar, en el cuerpo del texto (y entre paréntesis), el número de la página de cada fragmento citado. 
que su celebración de "La Cuba secreta" se traduzca en la celebración de una antología que recoge por primera vez poemas de este grupo de poetas. Cabe agregar que su satisfacción no se explica únicamente por el simple hecho de que esta generación poética exista. Al contrario, lo que le llama la atención es precisamente la calidad, y cualidad, de la poesía escrita por ellos. Porque resulta que, lejos de seguir ciegamente las modas intelectuales del momento (modas que, según Zambrano, se obsesionan con visiones angustiadas de la nada y del vacío), los jóvenes poetas cubanos escriben poemas inspirados en "la sobreabundancia del ser y sus riquezas". Es decir, escriben poemas de "la contra-angustia", que dan fe de esa misma "suntuosa riqueza de vida" (p. 110) que, como hemos visto, Zambrano asocia tanto con la isla de Cuba como con la poesía misma.

Si bien en su ensayo Zambrano se detiene en una afectuosa descripción de la poesía de cada uno de los diez poetas que conforman la antología, es sin duda en sus comentarios sobre la obra de Lezama (el poeta con quien se siente más estrechamente identificada) donde elucida con mayor claridad la visión poética que ella asocia con la isla. En todo caso, es al leer estos comentarios cuando vemos mejor perfilado el marco religioso en que dicha visión se inscribe. Y es que para ella, como para Lezama y sus amigos, la poesía supone una experiencia de lo sagrado: "La poesía permanece en lo sagrado y por ello requiere, exige, estado de permanente sacrificio. El sacrificio es la forma primera de captación de la realidad" (p. 111). Esta primera observación suya tal vez resulta un poco crítica, pero el sentido se aclara cuando, un poco más adelante, ella relaciona el trabajo del poeta con el mito de Orfeo. Y es que para ella el poeta debe estar dispuesto a renunciar a las formas actuales que rigen nuestra visión convencional del mundo y, como Orfeo, descender a las tinieblas del mundo informe, al oscuro recinto de los sentidos, para desde allí rescatar la imagen nueva e insólita que dé trascendencia a la vida, que permita que la vida alcance un estado de gracia, de perpetuo amanecer. Y esta es justamente la cualidad, la predisposición sacrificial, que descubre en la obra de su amigo Lezama.

Habría mucho más que decir, sin duda, sobre esta visión órfica que Zambrano nos ofrece tanto de Cuba como de sus poetas. En todo caso, lo que sí resulta evidente es que "La Cuba secreta", cuando es comparado con los otros dos ensayos que hemos comentado, acusa una evolución importante en el pensamiento de la autora. La historia no ha desparecido por completo del 
horizonte intelectual de la pensadora (en algún momento ella insiste que la poesía es una forma de actuar sobre la realidad, de definir y transformar la cultura de un país); pero, como hemos visto, sí empieza a desempeñar un papel secundario frente a la poesía, entendida también, y sobre todo, como una manera de ingresar a lo sagrado.

\section{UN DESCENSO A LOS INFIERNOS}

El primer país latinoamericano en el que se refugió María Zambrano después de la derrota de la República fue México, país al que llegó, junto con su marido, en marzo de 1939. Los dos exiliados pudieron hacer este viaje gracias a una invitación que recibió Zambrano a formar parte de La Casa de España en México, una institución creada hacia finales de 1938 por el Gobierno de México justamente con la finalidad de acoger a algunos de los más destacados intelectuales españoles obligados a abandonar su país a raíz de la Guerra Civil. Si bien la mayoría de los miembros de esta Casa, al llegar a México, se instalaron en la capital mexicana, tocó a la filósofa malagueña mudarse, casi en seguida, a la ciudad de Morelia, para cumplir con el encargo de dar clases de filosofía, sociología y psicología en la Universidad Michoacana. Este trabajo le resultó difícil, no sólo por la excesiva carga de clases que supuso, sino también porque la propia universidad, dirigida entonces por un joven rector de ideas firmemente socialistas, esperaba que Zambrano orientara sus clases hacia el marxismo, cosa que la antigua alumna de Ortega y Gasset era incapaz de hacer, tal y como ella, por otra parte, señalaba a sus superiores. Ambos inconvenientes, junto con el aislamiento intelectual en que se encontró de repente viviendo, probablemente influyeron en su decisión de aceptar dar una serie de conferencias en La Habana en enero de 1940. Impedida a volver a México por una enfermedad, que se vio agravada por un agotamiento físico muy grande, Zambrano terminó quedándose en Cuba y, así, puso fin, algo inesperadamente, a su breve estancia en Morelia.

Los ocho meses que pasó en México fueron muy fructíferos ${ }^{9}$. Y es que, además de dar clases en la universidad de Michoacán,

9 Para una detallada descripción de esta visita, véase el estudio de Francisco Javier Dosil Mancilla, "La sombra de un destino. El exilio de María Zambrano en Morelia”, en María Zambrano. 1904-1991..., pp. 111-137. 
Zambrano dio una serie de conferencias en el Distrito Federal, colaboró en varias revistas de América Latina, publicó dos libros: Filosofía y poesía y Pensamiento y poesía en la vida española, y también anunció estar trabajando en otros tres: Don Miguel de Unamuno y su obra, Breve historia de la mujer y El estoicismo como fenómeno de crisis histórica. Como indican estos cinco títulos, México no fue objeto de su reflexión en ese momento. Y de hecho, pese a algunos comentarios incluidos en las cartas que escribió por aquellos meses (comentarios que señalan que finalmente no lo pasó tan mal en Morelia como su repentino abandono del país tal vez da a entender), tenemos que esperar muchos años para dar con algún texto suyo en que nos brinde una reflexión a fondo sobre ese país. El texto que propongo comentar es una reseña de cierta extensión escrita con motivo de la aparición en 1959 de una segunda edición de El laberinto de la soledad, de Octavio Paz (libro publicado por primera vez en 1950$)^{10}$.

Como todos saben, la monografía de Paz se destaca sobre todo por el diagnóstico que ofrece de México, de su historia, de su cultura y de la psicología de sus habitantes. Un temario amplísimo, que el autor analiza recurriendo a enfoques muy variados, que ponen en juego, junto con consideraciones políticas, históricas o psicológicas, otras de orden más bien filosófico, poético o incluso religioso. En su reseña Zambrano no ignora por completo los aspectos históricos y sociológicos del libro, pero fiel a la orientación ya observada en su ensayo sobre Cuba, opta por leer la obra como una indagación filosófica y poética, o (para emplear sus palabras) como una "aventura en las más íntimas capas del ser”. De ahí el título órfico de su trabajo: "Un descenso a los infiernos" (p. 17). Y es que, fiel a una de las líneas interpretativas de Paz, Zambrano presenta la soledad del hombre moderno no sólo como un desamparo angustioso, sino también, y sobre todo, como una prueba: como la puerta de entrada a un proceso de iniciación, o purificación, por el cual el hombre tiene que pasar para poder salir de las tinieblas y alcanzar la luz.

Su decisión de subrayar esta lectura órfica a expensas de los demás enfoques que se encuentran en el libro de Paz, segura-

${ }^{10}$ Véase María Zambrano, "Un descenso a los infiernos", en Homenaje a María Zambrano, El Colegio de México, México, 1998, pp. 15-22. Al citar esta edición, me limito a identificar, en el cuerpo del texto (y entre paréntesis) el número de la página de cada fragmento citado. 
mente refleja preocupaciones de la filósofa malagueña; pero conviene señalar que esta interpretación, que reconcilia una búsqueda poética con otra de índole religiosa, coincide, en términos generales, con las ideas expresadas por Paz, quien también plantea la soledad como una especie de prueba que el hombre moderno tiene que asumir y superar para así escapar de su enajenación actual y alcanzar la comunión con los demás. De hecho, no es imposible que Paz haya llegado a formular su propuesta gracias en parte a ensayos escritos por Zambrano a lo largo de los años cuarenta ${ }^{11}$.

Ahora bien, es la segunda mitad de la reseña de María Zambrano que resulta de especial interés para el tema que venimos examinando aquí. Porque es en estas páginas finales cuando ella empieza a referirse a ciertos aspectos concretos de la cultura mexicana y cuando, al hacerlo, también expresa una importante discrepancia frente a la visión expresada por el autor de El laberinto de la soledad. Dicha diferencia, como veremos ahora, se debe, sobre todo, al sentido eminentemente teológico que Zambrano quiere asignar a la experiencia de la soledad.

"Las «categorías de vida» que Octavio Paz descubre -señala Zambrano- son categorías de lo sagrado" (p. 19). Esta afirmación resulta algo equívoca, en el sentido de que las categorías

11 La dialéctica de "soledad y comunión" que recorre todo el libro de Paz es planteada por él, por primera vez, creo, en un ensayo suyo publicado en 1944 bajo el título de "Poesía de soledad y poesía de comunión". Algo parecido puede encontrarse, ya en 1940, en el ensayo de Zambrano sobre Puerto Rico: "Soledad abierta. Imagen de la vida humana en los instantes de gracia en que flota en equilibrio, entre la soledad radical, raíz de su propia existencia, y el fuera, donde, llenos de nuestra interior verdad, vamos a buscar a los demás" (p. 23). Resulta curioso observar que incluso en su ensayo sobre "La tierra de Arauco", de 1938, Zambrano planteaba la misma oposición binaria. Refiriéndose al cambio de horizonte ideológico ocurrido en España al estallar la Guerra Civil, la filósofa malagueña había escrito, por ejemplo, lo siguiente: "Volvíamos a tener pasado, porque teníamos porvenir y a la luz del porvenir es como únicamente el pasado se manifiesta. El volumen íntegro de nuestras posibilidades apareció; el horizonte de América, claro y nítido en su inmensidad, se descubría desde nuestra soledad. Soledad necesaria para la inminente convivencia" (art. cit., las cursivas son mías). Lo que será "comunión" para Paz es "convivencia" para Zambrano; pero la idea es la misma. Por otra parte, no deja de llamar la atención el que Zambrano, al diagnosticar el problema que vive el roto chileno, pregunte justamente por las causas de la soledad que éste vive, de la misma manera en que, en $E l$ laberinto de la soledad, Paz iniciará la radiografía de su país preguntándose por la soledad de otro marginado, el pachuco mexicano. 
empleadas por Paz no ubican la discusión únicamente en el ámbito de lo sagrado; aunque sí es cierto que el ensayista mexicano acude en algún momento a esta forma de interpretar la historia y de la cultura de su país. "Todo cambio histórico es un cambio de los Dioses", afirma Paz, por ejemplo, articulando así una idea que Zambrano se apresura en citar (p. 20). Sin embargo, Paz difícilmente hubiera aceptado la conclusión que saca Zambrano de esta interrelación entre los dos órdenes, la historia y la religión. Y es que la pensadora malagueña relaciona la soledad del mexicano con una visión de la Conquista que es muy distinta de la que se puede leer en el libro de Paz:

Esta situación [la soledad del mexicano] puede definirse tal vez diciendo que el mexicano vive bajo el eclipse de Dios, en un momento en que sus Dioses parecieron abandonarlo y el nuevo Dios no ha engendrado la apertura del hombre. El hombre ofrece así resistencia a lo sagrado. Estar cerrado es resistir. La apertura es siempre una herida (p. 20).

Según Octavio Paz, la Conquista supuso para los indios la simple sustitución de un pensamiento religioso por otro, si bien en el catolicismo asumido por los indios sí sobrevivían muchos y muy diversos elementos precortesianos. "La huida de los dioses y la muerte de los jefes", explica Paz, "habían dejado al indígena en una soledad tan completa como difícil de imaginar para un hombre moderno. El catolicismo le hace reanudar sus lazos con el mundo y el trasmundo. Devuelve sentido a su presencia en la tierra, alimenta sus esperanzas y justifica su vida y su muerte"12. Es decir, con la llegada de los españoles, los indígenas mexicanos finalmente no vivieron una ruptura total con sus propios ritos religiosos ni con el ámbito de lo sagrado en general. Para María Zambrano, en cambio, como acabamos de ver, la derrota del imperio azteca por los españoles supuso una orfandad completa y permanente que llega hasta el siglo xx. Si el mexicano moderno se negaba a unirse a la colectividad, a incorporarse a la historia, era porque, al igual que su antepasado del siglo XvI, no sentía al nuevo Dios como suyo. Según luego agrega Zambrano:

nacer es estar comprometido en el juego de la historia. Ciertamente, el quehacer humano es la historia y no es posible vivir

12 Octavio Paz, El laberinto de la soledad, ed. A. Stanton, Manchester University Press, Manchester, 2008, p. 119. 
humanamente sin hacerla y padecerla. Pero en ese hombre mexicano preso en su laberinto, resulta evidente la resistencia a la historia, su hermetismo ante la forma del vivir histórico. No ante esta época o este modo de historia, ante esta o la otra cultura, sino ante toda historia (p. 20).

Al hablar del hombre mexicano, ¿María Zambrano se refiere únicamente al indio? ¿O querrá decirnos que la cultura del pasado indígena sigue pesando en el espíritu del mestizo moderno más que cualquier otro estímulo o presión cultural? Sea como sea, su interpretación teológica de la historia mexicana resulta bastante discutible, y eso por la sencilla razón de que, para cualquiera que haya visitado el país, es notorio el fervor con que los mexicanos (y sobre todo los indios) han hecho suya la fe cristiana que les fue inculcada a sus antepasados por los misioneros españoles. La desconfianza del mexicano ha sido únicamente con respecto al orden político y social. Su soledad, podríamos decir, tiene causas históricas, mas no religiosas. En ese sentido la versión de la Conquista que ofrece Paz en su libro parece ajustarse un poco más a los hechos que la versión formulada por María Zambrano en su resumen. Aunque, dicho esto, quisiera recalcar que no es mi propósito aquí desacreditar las ideas de la filósofa española, sino simplemente señalar la originalidad de su postura.

Cabe agregar que dicha originalidad interpretativa parece obedecer a su vez a una fascinación muy grande que la religión de los antiguos aztecas ejerce sobre la autora y que se vuelve explícita al final de su ensayo. Allí, en los últimos párrafos, introduce un curioso cambio de enfoque: lo que hasta ahora ha sido sólo un planteamiento teórico suyo, de repente se convierte en el testimonio de alguien que, en efecto, ha estado en México y que de una experiencia de primera mano ha sacado sus propias conclusiones sobre la religiosidad de quienes habitan el país:

Por mi parte me pareció encontrar en tierras de México una especie de nostalgia del sacrificio humano, como clave última de todas las formas en que el mexicano entrega su vida por... porque sí, por nada. Esta nada puede ser el vacío de los antiguos Dioses desaparecidos sustituido -en el corazón del hombre- por la imagen del Dios nuevo. De todo el libro de Octavio Paz-de este y de todos los suyos- se desprende esa atmósfera de sacrificio, esa luz amarillenta que yo he visto en México a la caída del sol, dorando las casas, envolviendo la cabeza del indio, señalando el perfil del 
horizonte. Luz sagrada, de sacrificio, en que el sol se despide de la tierra quizá con insatisfacción de llevarse su alimento. Y me pareció sentir que morían y mataban por eso, porque el sol no transpusiera solo el horizonte (p. 22).

Es decir, por una extraña paradoja, los dioses mexicanos, aunque desaparecidos hace siglos, siguen presentes en quienes instintivamente los añoran. Según Zambrano, el Dios impuesto a los indios es finalmente un sustituto falso, que no puede saciar la necesidad, consciente o inconsciente, de un rito sacrificial de orden muy distinto. De ahí la desconfianza del mexicano, de ahí su soledad: se halla privado de sus dioses verdaderos.

\section{BALANCE FINAL}

Los cuatro textos que hemos comentado representan sólo una pequeñísima selección de todo cuanto María Zambrano escribió sobre América Latina, sobre sus poetas y pintores, lo mismo que sobre sus paisajes. Sin duda, un examen a fondo del tema permitiría sacar conclusiones más matizadas acerca de las múltiples y muy variadas relaciones de la filósofa con América Latina. Pese a esta limitación, creo que los ensayos comentados dan cierta idea de la evolución del pensamiento sobre América que Zambrano fue desarrollando durante un período de más de veinte años. La idea de evolución es algo que quisiera subrayar en estas palabras finales, porque, al hablar de la experiencia de los exiliados españoles en América, se tiende con demasiada frecuencia a etiquetarlos según una visión o actitud adoptada por ellos en un primer momento. Es decir, no siempre se contempla la posibilidad de que en la visión de tal o cual escritor se haya registrado algún cambio o modificación. Lo cual es obviamente muy injusto, y más todavía en el caso de aquellos españoles que, como María Zambrano, vivieron un exilio de treinta o hasta de cuarenta años. En este sentido creo que la evolución que se observa en el pensamiento "americanista" de la filósofa malagueña puede resultar instructiva, no sólo para seguir la curva que traza su desarrollo intelectual, sino también para apreciar las tensiones que vivieron una buena parte de los intelectuales españoles a lo largo de su exilio.

En primer lugar, me llama la atención que el texto de 1938, escrito con motivo del viaje a Chile, arranque con una confesión 
que hubiera sonado escandalosa en su momento, si no fuera porque encontrara eco en la experiencia de muchos de los republicanos españoles. Me refiero a la confesión que hace Zambrano de no haber tomado conciencia alguna de América Latina hasta que estallara la Guerra Civil. "¿A qué negar que los españoles, vueltos de espaldas, como estábamos, a nuestro propio ser, lo estábamos también hacia América?", se pregunta al arrancar su ensayo, para luego contestar con sinceridad: "Enajenados de nosotros mismos, teníamos que estar enajenados de América. Ninguna influencia organizada sobre ella, ninguna acción coherente; poca, muy poca atención y menos memoria todavía de nuestro pasado creador”. ¿Cuántos españoles no habrán sentido este mismo remordimiento de conciencia al tocar tierra americana en los primeros días de su forzoso exilio ${ }^{13}$ La única diferencia en el caso de Zambrano es que ella no tuvo que esperar hasta el final de la guerra para tener su primer encuentro con el Nuevo Mundo.

El ensayo sobre el viaje a Chile deja en evidencia otro asunto que también resulta importante para entender la actitud de muchos exiliados hacia las sociedades latinoamericanas en que se refugiaron. Y es que, al leer este texto escrito en plena Guerra Civil, vemos cómo la visión netamente nacionalista con que Zambrano se acercó a "La tierra de Arauco" venía fomentada por los intelectuales chilenos que, en su deseo de socorrer a la República española en su lucha contra el fascismo, se mostraban más que dispuestos a asumir una actitud filial hacia la Madre España. Si los poetas chilenos pusieron ese título de Madre España a la antología de poesía publicada en homenaje a la República, y si esta postura de complaciente sumisión a la metrópoli caracterizaba también la conducta de muchos de los latinoamericanos que fueron a España durante la guerra con el fin de expresar su solidaridad con la causa, ¿por qué ha de sorprendernos que María Zambrano haya hecho suyo ese mismo discurso en su ensayo de 1938 y que muchos otros intelectuales

13 Véase, por ejemplo, las palabras que LUis CERNUdA coloca al frente de sus Variaciones sobre tema mexicano (1952): "En tu niñez y en tu juventud, ¿qué supiste tú, si algo supiste, de estas tierras, de su historia, que es una con la tuya? Curiosidad, confiésalo, no tenías. Culpa tuya, sin duda; pero nada en torno podía tampoco encaminarla. Lo que oías, cuando algo oías, frases políticas al uso, carentes por tanto de sinceridad y vacías de pensamiento, más era para matar toda curiosidad" (Obra completa, t. 1: Poesía completa, eds. D. Harris y L. Maristany, Siruela, Madrid, 1993, p. 622). 
lo repitieran, al poco tiempo de exiliarse en tal o cual país de América Latina? El malentendido, que suponía una continuación del viejo discurso paternalista, lo habían fomentado las dos partes y no sólo los españoles ${ }^{14}$.

El ensayo de 1940 sobre Puerto Rico resulta esclarecedor por un motivo muy distinto: por reflejar la influencia que la Segunda Guerra Mundial tuvo en la conciencia de los exiliados españoles en los primeros años de su destierro (que es otro tema que sospecho no ha sido suficientemente explorado por los estudiosos). Con el estallido de la Guerra Mundial, se hizo evidente a muchos republicanos que la posibilidad de que Franco cayera y de que ellos pudiesen volver a su país dependía ahora del desenlace de dicha guerra. Si bien con el tiempo la victoria de los aliados parecía más o menos segura, en los primeros dos años del conflicto mundial (es decir, antes de que Estados Unidos se declarara en guerra), la situación de los Aliados se veía, al contrario, muy precaria. De hecho, toda Europa parecía a punto de ser devorada por el fascismo de Hitler. De ahí las discusiones entre los exiliados sobre el futuro de Europa. A diferencia de quienes creían que la Vieja Europa simplemente había muerto, y también a diferencia de aquellos otros, como Juan Larrea, que creían que Europa había fenecido para renacer transfigurada en el Mundo Nuevo, María Zambrano se negó a aceptar que el Viejo Mundo hubiera muerto. En una actitud que muchos de sus colegas compartían, insistía en que el continente americano tenía un papel importante que desempeñar en la salvación de Europa, precisamente porque, a su juicio, valores elementales hermanaban los dos continentes. Aunque dicho esto, hay que reconocer que fue algo singular, en cambio, su decisión de

14 Para documentar la actitud hacia España que expresaron los intelectuales latinoamericanos durante la Guerra Civil sería interesante consultar sus colaboraciones en las revistas españolas de la época y muy particularmente en la ya mencionada Revista de las Españas, una publicación mensual que, aun cuando creada originalmente en Madrid en los años veinte, fue resucitada en Barcelona, en el verano de 1938, justamente con el fin de promover vínculos culturales más estrechos entre el Gobierno de la República Española y los sectores más progresistas de los países latinoamericanos. Fue a su vez órgano de la Unión Iberoamericana, de cuya dirección Zambrano fue elegida "vocal" en febrero de 1938 (véase la nota anónima, "La Unión Iberoamericana. Nueva directiva”, La Vanguardia [Barcelona], 13 de febrero de 1938, p. 3). Fueron elegidos Presidente de la Unión, Enrique Díez-Canedo; Vice-Presidente, Corpus Barga; y Bibliotecario, León Felipe. La revista la dirigía Corpus Barga, mientras que Zambrano figuraba entre los Redactores. 
apoyar una propuesta panamericanista, que suponía una difícil conciliación de las dos culturas americanas: la hispana y la sajona. Fue una propuesta, de hecho, que estaba en abierta contradicción con el rechazo que ella misma llevaba años haciendo con respecto al espíritu pragmático y tecnológico de las culturas sajonas. Y tal vez por eso, por su carácter circunstancial, este panamericanismo suyo sería de poca duración.

Desde luego, la forma en que Zambrano explica su relación con Cuba no podría ser más distinta de la aproximación a Chile y a Puerto Rico evidenciada en los dos primeros ensayos. Al hablar de aquellos otros dos países latinoamericanos, lo hizo presionada sobre todo por las dramáticas circunstancias históricas en que se encontraba viviendo: primero, la Guerra Civil española y, después, la Segunda Guerra Mundial. Al contemplar tanto a Chile como a Puerto Rico, iba en busca de valores españoles y europeos que ella temía fueran a quedar destruidos. En los años de la posguerra, en cambio, Zambrano demuestra haber evolucionado en su pensamiento hacia una visión del mundo en que cuestiones de orden poético ahora predominaban sobre las inquietudes políticas. Este cambio (que seguramente refleja el nuevo orden político en el panorama internacional que trajo el desenlace de la Segunda Guerra Mundial y, más particularmente, la renuencia de las grandes potencias a intervenir en España para derrocar a Franco) supone una paulatina superación de valores tanto nacionalistas como europeizantes, y se persigue siempre en busca de una visión de mayor universalidad.

En este sentido conviene recordar la distinción entre dos tipos de exiliado que establece Claudio Guillén en su hermoso libro El sol de los desterrados: por un lado, destaca aquel que, fiel al ejemplo de Ovidio, no puede recuperarse del gran golpe que ha sido para él la expulsión de su país, y que por lo mismo pasa el destierro obsesionado con una sola idea: la de la vuelta; y por otro, señala el desterrado que, siguiendo más bien la actitud de Plutarco o Séneca, no sólo no ve mal alguno en el exilio, sino que al contrario celebra la ocasión que el destierro le brinda "de descubrir o de comprender más profundamente todo cuanto tiene en común con los demás hombres, uniéndose a ellos más allá de las fronteras de lo local y de lo particular"15.

15 Claudio Guillén, El sol de los desterrados, Quaderns Crema, Barcelona, 1995, p. 22. 
Lo que ejemplifica la llamativa evolución del pensamiento de Zambrano durante los años cuarenta, si la contemplamos dentro de este marco de referencia, sería precisamente la transición de una a otra postura ante el exilio. Tal vez respaldada por la conciencia de que el exilio iba en efecto para largo, hacia finales de los años cuarenta Zambrano parece renunciar a la posibilidad de la vuelta para entregarse de lleno al exilio, como una instancia que le permite concentrarse en todo cuanto hay de universal en la experiencia humana ${ }^{16}$.

El cuarto ensayo, sobre México, que data de finales de los años cincuenta, tiene mucho en común con el ensayo sobre Cuba: ambos se inspiran en la lectura de un libro; ambos encuentran, en el pensamiento de Paz lo mismo que en la poesía de Lezama y sus amigos, una expresión que revela la actitud creadora de los dos países; y ambos identifican esa actitud con un concepto órfico de la poesía. Lo que distingue "Un descenso a las tinieblas" es, desde luego, la atención prestada a los dioses, un asunto que apenas si figura en "La Cuba secreta", pero que sí encuentra un desarrollo muy amplio en el libro de Zambrano sobre El hombre y lo divino de 1955. En su ensayo sobre El laberinto de la soledad, Zambrano deja ver la intensa fascinación que ejercen sobre ella los dioses de los antiguos habitantes del valle de México. De hecho, es tal la atracción que, al leer el libro de Paz, se muestra ansiosa de sumergirse en aquel lejano mundo, cuya presencia había sentido, sin embargo, de forma tan viva y tan inmediata durante los meses de su estancia en aquel país. Se trata de una tentación que han sentido, por cierto, otros visitantes a México. Lo curioso en el caso de María Zambrano, o lo que nos interesa subrayar aquí, es que esta fascinación supone en la autora una actitud, si no crítica, al menos distanciada frente a su formación como española. Si bien en su ensayo sobre Chile, ella había interpretado la Conquista como un ejercicio civilizador, que difundió por el continente los valores de una cultura tan indispensable como la española, este mismo episodio lo interpreta ahora como una calamidad cósmica, como un trauma que dejó sin sus Dioses a toda una raza. Podríamos decir, en fin, que de los cuatro ensayos comentados, el último,

${ }^{16}$ Para una interpretación más detallada (y muy distinta) de este asunto, véase el sugerente trabajo de Francis Lough, "Exilio, mito e identidad nacional en María Zambrano", en España en la encrucijada de 1939. Exilios, cultura e identidades, eds. M. Jato, J.A. Ascunce Arrieta y M.L. San Miguel Casillas, Universidad de Deusto, Bilbao, 2007, pp. 69-87. 
sobre México, constituye el punto de mayor renuncia que hiciera Zambrano con respecto a su formación, así como el texto en que es mayor su esfuerzo por identificarse con lo otro, que suele ser el gran reto que América plantea a los europeos ${ }^{17}$.

Desde luego, con esto no quiero decir que si, en los primeros años del exilio María Zambrano volvió una y otra vez de Europa a América Latina fue en busca de los dioses mexicanos. Porque, como hemos visto, fue Cuba, no México, el país que le atraía como un imán: Cuba, con su vegetación exótica y su luz deslumbrante, pero también con sus jóvenes poetas en plena efervescencia. En Lezama y sus amigos Zambrano encontró creadores profundamente identificados con su propia visión órfica del mundo, que le ofrecían una forma de reconciliar los valores autóctonos de su país con una visión universal de la cultura. Durante los breves meses que estuvo en México, en cambio, Zambrano se había dado de bruces contra una sociedad atrincherada en un rígido nacionalismo oficial que, si bien decía defender la causa de los indígenas, en realidad, muy poco hacía porque su voz se escuchara. Es cierto que entre los mexicanos contaba con interlocutores como Octavio Paz y Alfonso Reyes, pero salta a la vista que la vida cultural de Cuba le resultaba más abierta, más libre, más afín a sus propios intereses. Y si bien es cierto que Quetzalcóatl nunca había volado por los cielos de La Habana, en Cuba sí se hacía muy presente, en cambio, una cultura de raíz africana que también contribuía de manera importante al gran atractivo que la isla ejercía en Zambrano, ofreciendo un fascinante contrapunto a la cultura de origen europeo, tal y como ella señalara, por ejemplo, al ocuparse de la obra de la gran antropóloga cubana, Lydia Cabrera ${ }^{18}$.

Resumiendo, podríamos decir que los constantes viajes de ida y vuelta entre Europa y América contribuyeron sin duda a fomentar en María Zambrano una actitud mediadora. Apo-

17 Los problemas que este encuentro supuso para los exiliados españoles han sido subrayados por Mónica Jato en su artículo "Hispanidad, mestizaje e indigenismo: algunas consideraciones en torno a la cultura del exilio español de 1939", en España en la encrucijada de 1939, pp. 15-30.

18 M. Zambrano, "Lydia Cabrera, poeta de la metamorfosis", Orígenes (La Habana), 1950, núm. 25; recogido en La Cuba secreta y otros ensayos, pp. 130-133. Como ejemplo de su constante interés por los dioses mexicanos, véase su reseña del libro de Laurette Sejourné, El universo de Quetzalcóatl, F.C.E., México, 1962, en "El señor de la Aurora", Semana (San Juan de Puerto Rico), 29 de abril de 1964, núm. 305; recogido en Con Dados de Niebla (Huelva), 2002, núms. 21/22, 56-58. 
yada por un concepto muy positivo del exilio, llegó a adquirir una visión universalista del mundo que finalmente le impidió seguir atrapada en los prejuicios nacionalistas que caracterizaban los discursos de un buen número de sus contemporáneos. Conviene recordar aquí que el exilio, entre otras cosas, brindó a los exiliados españoles la oportunidad de crear por fin ese diálogo espiritual entre dos continentes, del que se venía hablando en España cada Día de la Raza desde hacía más de un siglo. Muchos de ellos, es cierto, no supieron (o no quisieron) aprovechar esa oportunidad. María Zambrano, en cambio, fue uno de los exiliados que más se esforzaron para que esa aspiración no siguiera siendo una mera palabra vacía ${ }^{19}$.

JAMES VALENDER

El Colegio de México

${ }^{19}$ Este texto fue leído como conferencia plenaria en el Congreso Internacional "Geografías del exilio español republicano", que se celebró en la Universidad de Birmingham, Inglaterra, en el mes de septiembre de 2008. Quisiera expresar aquí mi agradecimiento a Frank Lough y a los demás profesores del Departamento de Español por la generosa acogida que me brindaron. 
